\title{
MODEL KONSEPTUAL KELEMBAGAAN MANAJEMEN RANTAI PASOKAN DAN MANAJEMEN PENGETAHUAN PADA INDUSTRI KREATIF
}

\section{Tri Joko Wibowo}

Teknik Industri Universitas Serang Raya

Email : rb.bowo@gmail.com

\section{ARTICLE INFO}

\section{Kata Kunci:}

Ekonomi Kreatif, Manajemen Pengetahuan, Small Medium Enterprise

\section{ABSTRACT}

Ekonomi kreatif diyakini dapat menjawab tantangan permasalahan dasar jangka pendek dan jangka menengah. Industri kreatif menciptakan iklim bisnis yang positif dan membangun citra serta identitas bangsa. Disamping perkembangan yang luar biasa, industri kreatif di Indonesia juga menghadapi persaingan yang kian ketat. Salah satu bentuk tantangan dan ancaman yang dihadapi oleh industri kreatif di Indonesia adalah perkembangan unsure teknologi \& knowledge base, kurangnya kelembagaan, pemasaran, kapasitas dan jaringan distribusi. Salah satu bentuk antisipasi ancaman ini adalah industri kreatif perlu melakukan upaya pengelolaan rantai pasokan. Persaingan ke depan bukan hanya persaingan individu industri melainkan persaingan rantai pasokan dari industri kreatif. Industri kreatif saat ini umumnya masih relative berada pada level small medium enterprise / perusahaan kecil menengah. Pada dasarnya berbagai permasalahan yang dihadapi oleh UKM cenderung berulang dari tahun ke tahun dan dari periode ke periode. Persoalan yang berulang ini menunjukan lemahnya pengelolaan pengetahuan. Paper ini bersifat konseptual yang merupakan hasil dari studi literature. Hal yang disarankan dalam paper ini adalah perlunya proses pelembagaan manajemen rantai pasokan dan manajemen pengetahuan pada industry kreatif. Proses pelembagaan tersebut digambarkan di dalam sebuah model yang menghubungkan antara kebijakan pendukung, mapping industry kreatif, kelembagaan manajemen rantai pasokan dan karakteristik pasar. Harapannya perkembangan industry kreatif dewasa ini bukan hanya sekedar trend melainkan memiliki tingkat keberlanjutan di masa mendatang. 


\section{PENDAHULUAN}

Ekonomi kreatif diyakini dapat menjawab tantangan permasalahan dasar jangka pendek dan jangka menengah : 1 . Relative rendahnya pertumbuhan ekonomi pasca krisis (rata-rata hanya 4,5\% per tahun), 2. Masih tingginya pengangguran (9-10\%), 3. Tingginya tingkat kemiskinan (16-17\%) dan 4. Rendahnya daya saing industry. Selain permasalahan tersebut, ekonomi kreatif ini juga diharapkan dapat menjawab tantangan seperti isu global warming, pemanfaatan energy terbarukan, deforestasi dan pengurangan emisi karbon karena arah pengembangan ekonomi kreatif ini akan menuju pola industry ramah lingkungan dan penciptaan nilai tambah produk dan jasa yang berasal dari intelektualitas sumber daya insani yang dimiliki oleh Indonesia, dimana intelektualitas sumber daya insani merupakan sumber daya terbarukan ${ }^{2}$.Indonesia perlu terus mengembangkan industri kreatif. Alasannya, industri kreatif memberikan kontribusi ekonomi yang signifikan. Selain itu, industri kreatif menciptakan iklim bisnis yang positif dan membangun citra serta identitas bangsa. Di sisi lain, industri kreatif berbasis pada sumber daya yang terbarukan, menciptakan inovasi dan kreativitas yang merupakan keunggulan kompetitif suatu bangsa serta memberikan dampak sosial yang positif ${ }^{3)}$.

Tahun 2013 pertumbuhan ekonomi kreatif mencapai 5,76\% atau lebih tinggi dari pertumbuhan ekonomi nasional 5,74\%. Kontribusi ekonomi kreatif sebesar 7\% terhadap PDB nasional dan menyerap 11,8 juta tenaga kerja atau sebesar $10,72 \%$ dari total tenaga kerja nasional serta menciptakan 5,4 juta usaha atau sekitar 9,68\% dari total jumlah usaha nasional dan berkontribusi terhadap devisa negara sebesar Rp 119 triliun atau sebesar 5,72\% dari total ekspor nasional. pemerintah telah mengindentifikasi tujuh isu strategis yang dapat menjadi potensi maupun tantangan yang perlu mendapatkan perhatian para pemangku kepentingan dalam pengembangan ekonomi kreatif mendatang. Ketujuh isu tersebut yakni;

(1) ketersediaan sumber daya kreatif yang profesional dan kompetitif; (2) ketersediaan sumber daya alam yang berkualitas, beragam, dan kompetitif; (3) sumber daya budaya yang dapat diakses secara mudah; (4) industri kreatif yang berdaya saing, tumbuh, dan beragam; (5) ketersediaan pembiayaan yang sesuai, mudah diakses, dan kompetitif. Kemudian, (6) ketersediaan infrastruktur dan teknologi yang sesuai dan kompetitif; (7) kelembagaan yang mendukung pengembangan ekonomi kreatif ${ }^{5)}$.

Tabel Perkembangan Ekonomi Kreatif Dari Berbagai Sektor Dari Tahun 2011-2015

\begin{tabular}{|l|l|r|r|r|r|c|}
\hline No & Lapangan Usaha & 2011 & 2012 & 2013 & 2014 & 2015 \\
\hline 1. & Industri Makanan dan Minuman & $5,24 \%$ & $5,31 \%$ & $5,14 \%$ & $5,32 \%$ & $5,61 \%$ \\
\hline 2. & Industri Tekstil dan Pakaian Jadi & $1,38 \%$ & $1,35 \%$ & $1,36 \%$ & $1,32 \%$ & $1,21 \%$ \\
\hline
\end{tabular}





\begin{tabular}{|l|l|l|l|l|l|l|}
\hline 3. & $\begin{array}{l}\text { Industri Kulit, Barang dari Kulit } \\
\text { dan Alas Kaki }\end{array}$ & $0,28 \%$ & $0,25 \%$ & $0,26 \%$ & $0,27 \%$ & $0,27 \%$ \\
\hline 4. & $\begin{array}{l}\text { Industri Kayu, Barang dari Kayu } \\
\text { dan Gabus dan Barang Anyaman } \\
\text { dari Bambu, Rotan dan Sejenisnya }\end{array}$ & $0,76 \%$ & $0,70 \%$ & $0,70 \%$ & $0,72 \%$ & $0,67 \%$ \\
\hline 5. & Industri Furnitur & $0,28 \%$ & $0,26 \%$ & $0,26 \%$ & $0,27 \%$ & $0,27 \%$ \\
\hline 6. & Ekspor Kerajinan Tangan & & $15.54 \%$ & $17.77 \%$ & $20.18 \%$ & $21.72 \%$ \\
\hline 7. & Fashion dan kerajinan & $15 \%$ & $20 \%$ & & & \\
\hline 8. & Industri Periklanan & $24,8 \%$ & & \\
\hline
\end{tabular}

Sumber: BPS, Pusdatin Kemenperin

\section{METODE}

Paper ini merupakan hasil dari kajian pustaka. Pencarian literatur dilakukan dengan searching dengan mesin pencari (google). Topik yang dicari adalah terkait dengan industri kreatif, rantai pasokan, manajemen pengetahuan dan pihak-pihak yang terkait dengan pemberdayaan industri kreatif.

\section{HASIL PEMBAHASAN}

\subsection{Analisa SWOT (Strengh, Weakness, Opportunity, Threatment) Industri Kreatif di Indonesia}

Disamping perkembangan yang luar biasa, industri kreatif di Indonesia juga menghadapi persaingan yang kian ketat. Pesaing datang dari dalam maupun luar negeri. Nurul Istifadah (2012) melakukan riset untuk menganalisa kekuatan, kelemahan, peluang dan ancaman industri kreatif di di Indonesia memiliki kekuatan. Hasil analisanya sebagai berikut ${ }^{7)}$ :

- Kekuatan(Strength)ekonomi kreatif di Indonesia: merupakan sektor inovatif dengan nilai tambah yang besar, inputnya merupakan ide/gagasan dan kreativitas yang terbarukan, production cost yang relatif murah, kontribusinya ke PDB nasional yang cukup besar, menyerap banyak tenaga kerja, meningkatkan ekspor dan daya saing internasional, memiliki dampak positif dan keterkaitan yang tinggi dengan sektor lainnya, menciptakan citra dan identitas bangsa (tourism, membangun budaya dan nilai lokal), output dan proses produksinya merupakan green community yang tidak merusak lingkungan dan meningkatkan kualitas hidup serta toleransi sosial, mempunyai potensi yang masih besar, karena Indonesia mempunyai golongan penduduk muda yang berjumlah $43 \%$ dimana merupakan kekuatan sumber daya manusia yang sangat besar dan memiliki ide kreatif yang tidak terbatas, Memiliki potensi keragaman warisan budaya dan nilai-nilai lokal.

- Kelemahan(Weakness)pengembangan ekonomi kreatif di Indonesia: banyaknya pembajakan karya dan banyak produk ekonomi kreatif yang belum diproteksi oleh hak kekayaan intelektual, rendahnya daya beli masyarakat yang menyuburkan praktek pembajakan atas karya-karya 
kreatif. Hal ini mengakibatkan pupusnya ide-ide kreatif dan terjadinya proses degradasi kreativitas, kemampuan sumber daya masih perlu ditingkatkan, pendidikan di bidang industri kreatif masih sangat kurang, padahal kontribusi industri kreatif dalam perekonomian nasional terus meningkat, kualitas output industri kreatif Indonesia masih rendah dibanding dari negara lain (terutama di tingkat ASEAN), permasalahan/kendala pembiayaan dimana masih belum diakuinya aktivitas ekonomi kreatif oleh perbankan membuat mereka tidak didukung permodalan bank. Keterbatasan modal menyebabkan terpangkasnya kreativitas karena mereka hanya bekerja berdasarkan pesanan, bukan dari gagasan sendiri, dukungan pemerintah yang relatif masih baru dibanding dengan sektor ekonomi lainnya yang lebih dulu berkembang, kurangnyakeahliandi bidang pemasaran

- Tantangan (Opportunities) pengembangan ekonomi kreatif di Indonesia adalah:adanya perlindungan haki dan lingkungan yang semakin baik agar inovasi dapat berkembang, era global yang memberi peluang berkembangnya ide/gagasan, kreativitas, unsur tehnologi dan knowledge base, ekonomi kreatif Indonesia memiliki keunggulan kompetitif, memberikan peran yang lebih luas dalam memperbaiki citra pariwisata nasional serta kemampuannya mengangkat budaya lokal, Memiliki tenaga-tenaga kreatif, inovatif, dan andal yang memiliki jenjang pendidikan di bidang industri kreatif.

- Ancaman(Threats) pengembangan ekonomi kreatif di Indonesia meliputi:penjiplakan karya oleh negara lain, keterbatasanuntuk mendapatkanpembiayaan, kurangnya hak cipta (HAKI), kurangnya kelembagaan, pemasaran kapasitas danjaringan distribusi, penguasaan teknologi, serta inovasiindustri kreatif

\subsection{Peningkatan Daya Saing Industri Kreatif melalui Management Rantai Pasokan dan Manajemen}

\section{Pengetahuan}

Salah satu bentuk tantangan dan ancama yang dihadapi oleh industri kreatif di Indonesia adalah perkembangan unsure teknologi \& knowledge base, kurangnya kelembagaan, pemasaran, kapasitas dan jaringan distribusi ${ }^{7)}$. Salah satu bentuk antisipasi ancaman ini adalah industri kreatif perlu melakukan upaya pengelolaan rantai pasokan. Persaingan ke depan bukan hanya persaingan individu industri melainkan persaingan rantai pasokan dari industri kreatif.

\subsection{Manajemen Rantai Pasokan}

Untuk meningkatkan daya saing pada industri kreatif, diperlukan adanya pengelolaan, baik secara internal ataupun eksternal perusahaan. Hubungan antara supplier, customer, dan perusahaan itu sendiri, harus dikelola dengan baik. Bagaimana agar supplier ikut bertanggungjawab terhadap kualitas 
produk, hubungan yang baik dan jangka panjang dengan supplier dan customer, serta agar distribusi produk dari hulu ke hilir tepat pada waktunya sampai ke pengguna akhir. Disinilah pengelolaan perlu dilakukan. Terjadi sebuah kesalahan pada distribusi barang dan jasa akan membuat kualitas barang dan jasa menurun. Dan ini berakibat daya saing melemah. Untuk meningkatkan distribusi barang dan jasa, serta sharing informasi dan financial dari hulu ke hilir pada sektor industri kreatif, maka diperlukan pengelolaan secara komprehensif. Penerapan dan praktek supply chain management untuk penyediaan barang dan jasa inilah yang sangat diperlukan bagi sektor industri kreatif, dalam rangka meningkatkan daya saing industri yang akan memberikan dampak pada kinerja usaha ${ }^{3)}$.

\subsection{Manajemen Pengetahuan}

Saat ini, penguasaan pengetahuan adalah kunci untuk memenangkan persaingan. Penguasaan pengetahuan dapat diwujudkan dalam bentuk teknologi, metode kerja dan budaya kerja. Meningkatnya daya saing UKM akan berpengaruh terhadap produkvitas dan kontribusi bagi negara. (Fajar, 2009). Sedangkan menurut Tambunan (2010), daya saing sebuah perusahaan tersebut ditentukan oleh tujuh faktor, yaitu (1) keahlian atau tingkat pendidikan pekerja, (2) keahlian pengusaha, (3) ketersediaan modal, (4) system organisasi dan manajemen yang baik, (5) ketersediaan teknologi, (6) ketersediaan informasi, serta (7) ketersediaan input-input lainnya ${ }^{9)}$.

Manajemen pengetahuan adalah manajemen pengetahuan adalah proses yang bersifat teknis, customize dan strategis di dalam pengelolaan pengetahuan sebagai asset perusahaan, yang mana proses tersebut dilakukan dari aspek pengelolaan faktor-faktor yang mempengaruhi keberhasilan implementasi manajemen pengetahuan, aspek proses pengetahuan (socialization, externalization, combination and internalization) sampai mengukur sejauh mana penggunaan pengetahuan akan meningkatkan kinerja perusahaan ${ }^{8)}$.

Industri kreatif saat ini masih relative berada pada level small medium enterprise / perusahaan kecil menengah. Pada dasarnya berbagai permasalahan yang dihadapi oleh UKM cenderung berulang dari tahun ke tahun, dari periode ke periode, namun demikian masih banyak UKM yang pada akhirnya harus gulung tikar karena tidak mampu menghadapi kondisi ini. Permasalahanpun semakin kompleks dan rumit ketika UKM harus berhadapan tidak hanya dengan masalah yang datangnya dari luar, tetapi juga masalah internal, seperti minimnya tingkat pendidikan pemilik usaha, kurangnya modal, terbatasnya jaringan distribusi dan pemasaran, produk dan pelayanan yang kalah bersaing, hingga manajemen internal yang terbatas, baik dalam hal pengetahuan maupun pengalaman. Salah satu solusi yang dapat dilakukan adalah dengan meng-implementasikan Knowledge Management dalam tubuh organisasi / perusahaan. Seperti yang telah dijelaskan, bahwa Knowledge Management 
menurut uriarte merupakan proses suatu organisasi menciptakan nilai yang bersumber dari asset organisasi yang berbasis pada pengetahuan dan intelektual. Asset UKM yang berupa tacit knowledge seperti pengetahuan yang dimiliki oleh setiap individu atau staff pada perusahaan merupakan modal berharga yang kemudian dapat dikembangkan menjadi keunggulan perusahaan ${ }^{9)}$.

\subsection{Model Penguatan Kelembagaan Management Rantai Pasokan dan Management Pengetahuan bagi}

\section{Industri Kreatif}

Kelembagaan merupakan fenomena sosial ekonomi yang berkaitan dengan hubungan antara dua atau lebih pelaku interaksi sosial ekonomi yang mencakup aturan-aturan yang disepakati oleh para pelaku interaksi, disertai analisis hasil akhir yang diperoleh dari interaksi yang terjadi (Taryoto,1995). Rantai pasok mengacu pada definisi yang dikemukakan oleh Harland (1996) yang mengemukakan bahwa: 'supply chain management (SCM) is the management of a network of interconnected businesses involved in the ultimate provision of product and service packages required by end consumers'. Kelembagaan rantai pasok pada hakekatnya menganalisis hubungan interaksi vertikal antar pelaku dalam rantai pasok. Secara vertikal kelembagaan peternakan rakyat yang terkait diantaranya adalah kelembagaan produksi peternakan rakyat, pemasaran, pengolahan, distribusi produk, dan pelaku di pasar konvensional/ modern ${ }^{4)}$.

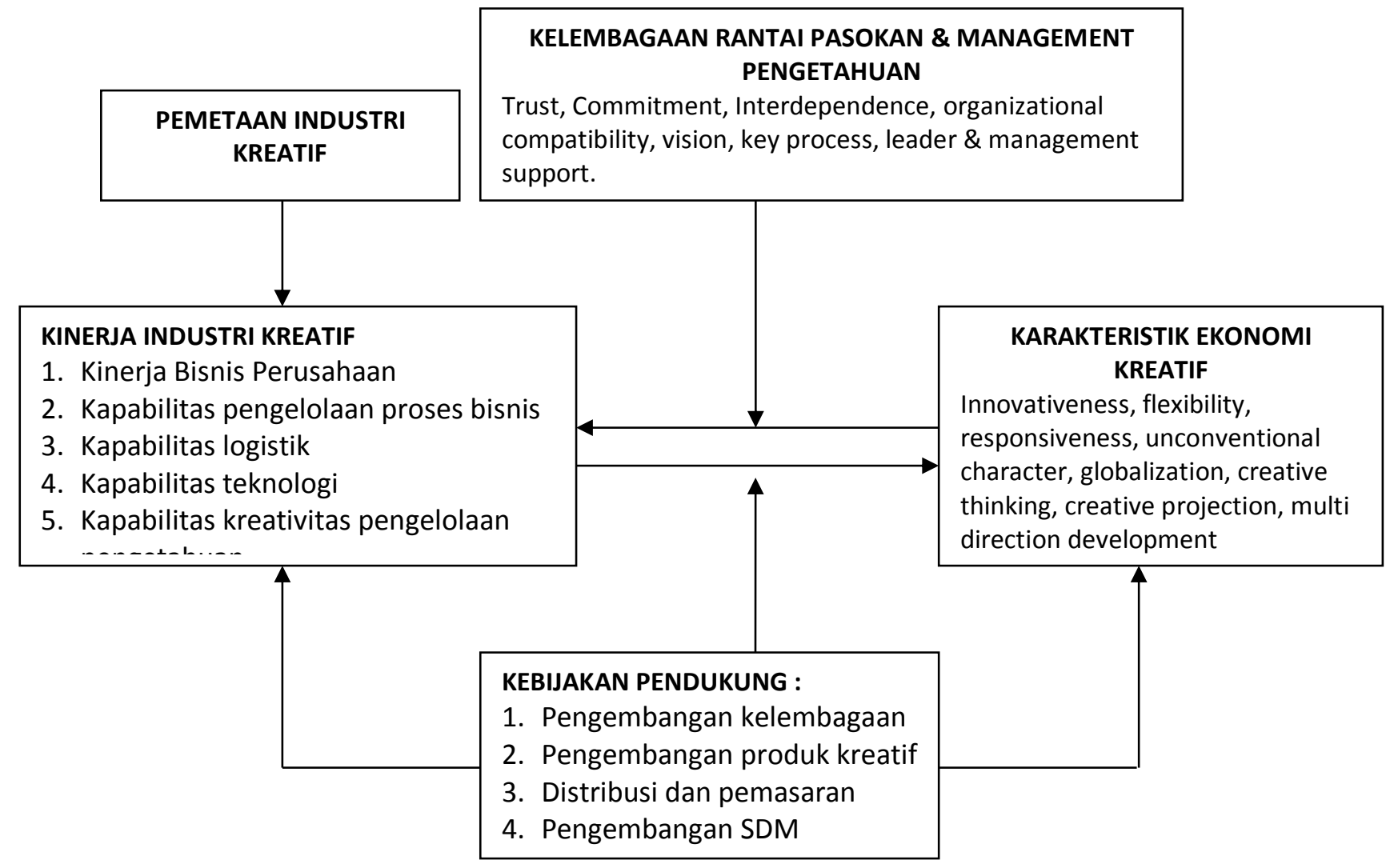

Gambar 1. Model Konseptual Kelembagaan Rantai Pasokan dan Pengetahuan 
Uraian dari masing-masing komponen di dalam gambar 1 adalah sebagai berikut :

1. Pemetaan Industri Kreatif

Bagi pembangunan ekonomi kreatif suatu daerah, penting dilakukan pemetaan industry kreatif. Tujuan pemetaan industry kreatif adalah untuk mengetahui profile industry kreatif, untuk mengetahuui kondisi saat ini \& mendatang mengenai industry kreatif, untuk merencakana arah pertumbuhan industry kreatif, untuk menyadarkan pihak penyusun kebijakan tentang industry kreatif dan untuk mendukung tujuan ekonomi dan politik secara luas ${ }^{15}$. Tanpa ada pemetaan maka arah ekonomi kreatif tidak akan sejalan dengan potensi yang di dalam masyarakat. Ekonomi kreatif sendiri dasarnya adalah potensi sumber daya insani yang ada di dalam masyarakat suatu daerah. Salah satu contohnya adalah pemetaan industry kreatif di Madura ${ }^{10)}$. Variabel yang dipakai untuk memetakan antara lain KBLI (Klasifikasi Baku Lapangan Usaha Indonesia. Dari hasil pemetaan didapatkan sekor industry kreatif unggulan yaitu kerajinan, desain fesyen dan video ${ }^{10)}$. Proses yang sama perlu dilakukan oleh daerah-daerah lainnya agar mendapatkan potret mengenai pengembangan industry kreatif yang perlu didorong.

2. Industri Kreatif

Kinerja suatu industry kreatif bisa dilihat dari kinerja bisnis yang ditopang oleh 3 kapabilitas antara lain kapabilitas pengelolaan proses bisnis internal, kapabilitas teknologi dan kapabilitas pengelolaan logistik ${ }^{12}$. Selain ketiga kapabilitas tersebut juga diperlukan kapabilitas kreativitas dan pengelolaan pengetahuan. Pengelolaan pengetahuan sangat terkait dengan kemampuan kreativitas. Kemampuan kreativitas sendiri memiliki 4 dimensi yaitu creativity fluency, creativity elaboration, creativity originality \& creativity flexibility ${ }^{14)}$.

3. Kebijakan Pendukung

Tahapan pemetaan industry kreatif perlu dilanjutkan dengan mendesain kebijakan yang sifatnya mendukung keberadaan industry kreatif. Salah satu contohnya adalah kebijakan ekonomi kreatif yang ada di Kabupaten Tuban ${ }^{11)}$. Disebutkan di dalam penelitian ${ }^{11)}$, kebijakan ekonomi kreatif Tuban dianalisis dalam beberapa hal seperti tata kelola ekonomi kreatif, masih kurangnya kualitas dan kapasitas SDM industry kreatif, masih lemahnya tata kelola di dalam pengelolaan usaha industry kreatif baru dalam hal kreasi, produksi \& distribusi produk, belum adanya payung hukum yang mengelola tata kelola masing-masing sub sektor industry kreatif dan lambannya percepatan adopsi teknologi informasi terkait pengembangan akses pasar dan inovasi.

4. Karakteristik pasar ekonomi kreatif

Industry kreatif pada dasarnya adalah jawaban dari kebutuhan yang muncul di di dalam 
perkembangan ekonomi kreatif. Sebagaimana karakter dari ekonomi kreatif yaitu innovativeness, flexibility, responsiveness, unconventional character, globalization, creative thinking, creative projection, multi direction development ${ }^{16)}$, maka industry kreatif harus mengikuti karakter dari ekonomi kreatif agar mendapatkan respon yang baik dari pengguna produk/layanan industry kreatif. Untuk bisa memiliki karakter ekonomi kreatif, internalisasi karakter tersebut di dalam masyarakat perlu didukung oleh kebijakan pendukung dari Pemerintah. Untuk melakukan internalisasi, Pemerintah bisa berkolaborasi dengan berbagai pihak salah satunya adalah dunia pendidikan (akademisi). Dunia pendidikan berperan untuk menghasilkan sumber daya insani yang kreatif melalui pendidikan kewirausahaan ${ }^{17)}$..

5. Kelembagaan rantai pasokan dan manajemen pengetahuan

Kelembagaan rantai pasokan di industri kreatif harus didasari oleh saling percaya, komitmen kerjasama yang tinggi, saling ketergantungan, pengelolaan organisasi yang saling bisa menyesuaikan, kejelasan visi, prioritas pada proses bisnis utama dan dukungan dari masingmasing manajemen dari industry kreatif ${ }^{13)}$.

\section{Simpulan}

1. Industri kreatif merupakan pendorong dalam tumbuhnya ekonomi kreatif. Sebagai pendorong maka diperlukan strategi yang tepat di dalam menumbuhkembangkan industry kreatif.

2. Salah satu strategi di dalam menumbuhkembangkan industry kreatif adalah adanya system kelembagaan yang merupakan wujud koordinasi dan kolaborasi antar industry kreatif dengan Pemerintah, Akademisi dan Komunitas industry kreatif

3. Model konseptual kelembagaan akan menjadi model dalam hal pemetaan industry kreatif, kelembagaan rantai pasokan, kebijakan pendukung dan pengembangan pasar industry kreatif

\section{Saran}

Model konseptual kelembagaan rantai pasokan dan pengetahuan perlu diuji dengan menggunakan metode structural equation modeling agar bisa menjadi acuan yang sifatnya umum bagi pihak-pihak yang berkepentingan. 


\section{DAFTAR PUSTAKA}

[1] https://www.kabar6.com/banten/serang/16035-pemprov-banten-dinilai-tak-fokus-urusi-industrikreatif

[2] Mari Elka Pangestu, 2008, Pengembangan Industri Kreatif Menuju Visi Ekonomi Kreatif Indonesia 2025, Departemen Perdangan RI

[3] Lisda Rahmasari, 2011, Pengaruh Supply Chain Management terhadap Kinerja Perusahaan dan Keunggulan Bersaing (Studi Kasus pada Industri Kreatif di Provinsi Jawa Tengah), Majalah Ilmiah Informatika Vol. 2 No. 3, September 2011.

[4] Wahyuning K Sejati, Analisis Kelembagaan Rantai Pasok Telur Ayam Ras Peternakan Ayam Ras Peternakan Rakyat di Jawa Barat, Analisis Kebijakan Pertanian Vol 9, No. 2, Juni 2011 : 183-198

[5] http://wartaekonomi.co.id/berita31674/inilah-tujuh-tantangan-sektor-ekonomi-kreatif-bagipresiden-2014.html

[6] http://lifestyle.liputan6.com/read/2545918/lezatnya-10-kuliner-top-di-banten

[7] https://www.researchgate.net/profile/Nurul_Istifadah/publication/291126222_Meningkatkan_Keu nggulan_Kompetitif_Nasional_Melalui_Pengembangan_Ekonomi_Kreatif_Menghadapi_Perekonomia n_Global/links/569e23df08ae9 50bd7a92003

[8] Wibowo, 2009, Validasi Hubungan antar Faktor-Faktor yang Mempengaruhi Implementasi Manajemen Pengetahuan, Laporan Tesis Magister Teknik Industri, Institut Teknologi Bandung.

[9] Kautsar, Ikhlas, 2011, Knowledge Management sebagai Keunggulan Kompetitif pada Usaha Kecil dan Menengah (UKM) : Implementasi dan Hambatannya, diakses 17 Februari2017 melalui :http://ikhlas35e.blogstudent.mb.ipb.ac.id/files/2011/01/Knowledge-Management-Sebagai-

Keunggulan-Kompetitif-Bagi-UKM-_-Implementasi-dan Hambatannya.pdf

[10] Akhmad dan Hidayat, 2015, Pemetaan Potensi Industri Kreatif Unggulan Madura, Jurnal Sains, Teknologi dan Industri, Vol 12, No. 2, Juni 2015, pp 155-165

[11] Amir, 2017, Kebijakan Ekonomi Kreatif Berbasis Industri Kerajinan Unggulan Dalam Upaya Mengangkat Kearifan Lokal Kabupaten Tuban, Jurnal Cakrawala Vol. 11 No.2 Desember 2017 : 157-169

[12] Hadi \& Parubak, 2016, Supply Chain Operational Capability Affecting Business Performance of Creative Industries, Advance in Economics Business \& Management Research, Vol 15

[13] Satyanegara, 2012, Analisis Manajemen Rantai Pasok pada Industri Batik Banten, Laporan Tesis, Sekolah Pascasarjana Institut Pertanian Bogor 
[14] Albonaiemi \& Ghahremani, 2016, Examining The Relation Between Knowledge Management \& Employee Creativity, International Journal of Humanities and Cultural Studies.

[15] BOP Consulting, 2010, Mapping The Creative Industries Toolkit, British Council

[16] Savina, et.al, 2015, Essence, Place and Role Of Creative Economy in Innovation Development Paradigm, Review of European Studies, Vol. 7, No. 6, Published by Canadian Centre of Science and Education

[17] Hasan, 2018, Pembinaan Ekonomi Kreatif dalam Perspektif Pendidikan Ekonomi, Jurnal Ekonomi dan Pendidikan, Volume 1, No. 1 Januari 2018, Hal 81-86 